\title{
Trace element partitioning between garnet and silicate-carbonate melt - an experimental study at 3.5-21 GPa in a carbonated eclogite system
}

\author{
KATE KISEEVA ${ }^{1}$, EMMA L TOMLINSON ${ }^{2}$ AND \\ GREGORY YAXLEY ${ }^{3}$ \\ ${ }^{1}$ University College Cork \\ ${ }^{2}$ Trinity College Dublin \\ ${ }^{3}$ Australian National University \\ Presenting Author: kate.kiseeva@ucc.ie
}

We experimentally investigated trace element partitioning for a range of LILe, HFSe, REE and transition zone metals in two nominally anhydrous, K-bearing, altered MORB compositions $\mathrm{GA} 1+10 \% \mathrm{CaCO}_{3}\left(\mathrm{GA} 1 \mathrm{cc}\right.$ ) and Volga $+10 \% \mathrm{CaCO}_{3}$ (Volgacc) from $1250-1650^{\circ} \mathrm{C}$ and $3.5-21 \mathrm{GPa}$. GA1cc models deep subduction of carbonated oceanic crust. Volga-cc models altered oceanic crust that may have lost its siliceous component during dehydration in the subduction zone. Detailed descriptions of the experimental procedure and experimental results are in Kiseeva et al. (2012).

Partition coefficients (D) between garnet and coexisting silicate-carbonate melt were precisely measured for 6 experiments by Laser Ablation Inductively Coupled Plasma Mass Spectrometry (LA-ICP-MS) for 29 trace elements (Co, La, $\mathrm{Ce}, \mathrm{Nd}, \mathrm{Pr}, \mathrm{Sm}, \mathrm{Eu}, \mathrm{Gd}, \mathrm{Tb}, \mathrm{Dy}, \mathrm{Ho}, \mathrm{Er}, \mathrm{Tm}, \mathrm{Yb}, \mathrm{Lu}, \mathrm{Ta}, \mathrm{Hf}, \mathrm{Sr}$, $\mathrm{Ba}, \mathrm{V}, \mathrm{Rb}, \mathrm{Y}, \mathrm{Zr}, \mathrm{Nb}, \mathrm{Cu}, \mathrm{Zn}, \mathrm{Ga}, \mathrm{Sc}, \mathrm{U})$ doped with an average amount of 100-1500 ppm each.

The data are in good agreement with previous studies on partitioning at both lower- (3.5-4.5 GPa) and higher- (17-21 GPa) pressure. The REE patterns for lower-pressure garnets is steeper and exhibits lower D's for the LREE and higher D's for the HREE compared with the higher pressure majoritic garnets. The D's for LREE vary between $0.04(\mathrm{La})$ and $0.7(\mathrm{Gd})$ for the majoritic garnet and between $0.01(\mathrm{La})$ and $0.37(\mathrm{Gd})$ for the 3.54.5 GPa garnet. For HREE however, D's vary between $0.98(\mathrm{~Tb})$ and $2.13(\mathrm{Lu})$ for majoritic garnet and between $0.63(\mathrm{~Tb})$ and $3.32(\mathrm{Lu})$ for the 3.5-4.5 GPa garnet.

All chalcophile and transition metal $(\mathrm{Sc}, \mathrm{V}, \mathrm{Mn}, \mathrm{Co}, \mathrm{Ni}, \mathrm{Cu}$, $\mathrm{Zn}, \mathrm{Ga})$ except $\mathrm{Cu}$ are compatible $(\mathrm{D}>1)$ in both high- and lowpressure garnets, with D's varying on average between $1.6(\mathrm{Ga})$ and $2.4(\mathrm{Sc})$.

In comparison with the literature data, D's for eclogitic garnets appear to be slightly higher than the D's for garnets in peridotitic system. Our findings have implications for modelling eclogitederived melts in the mantle and/or subduction-related melts during slab descent and for understanding the origin of majoritic inclusions in diamonds.

Kiseeva E.S. et al. (2012). JPET, 53 (4), p. 727-759. 